\title{
Study on Morpho-Physiological Traits in Isabgol (Plantago ovate Forsk.) Influenced by Different Fertilizer Levels
}

\author{
C. B. Kuchekar, Madane Ananda Jaganath*, P. P. Patil, \\ M. K. Hiwrale and P. D. Ghodke \\ Department of Agronomy, Banaras Hindu University, Varanasi -221 005, India \\ *Corresponding author
}

Keywords

Varieties, Fertilizer, Isabgol and Yield

Article Info

Accepted:

22 December 2019

Available Online:

20 January 2020

A B S T R A C T

A field experiment entitled Morphophysiological analysis of growth and yield of Isabgol (Plantago ovata Forsk) as influenced by fertilizer levels" was conducted at Dhanwantari farm, Department of Botany, Central Campus, MPKV, Rahuri, Dist. Ahmednagar (MS) during rabi season of 2006 - 07. An experiment was laid out in a factorial randomized block design (FRBD) with four replications. In this experiment three varieties (V1:GI-1, $\mathrm{V}_{2}: \mathrm{HI}-5$ and $\mathrm{V}_{3}$ :Niharika) with two fertilizer levels ( $\mathrm{L}_{1}$ :50:25:00, $\mathrm{L}_{2}:$ 100: 50: $00 \mathrm{NPK} \mathrm{kg/ha)} \mathrm{were} \mathrm{used.} \mathrm{The} \mathrm{observations} \mathrm{on}$ different morphological characters viz., Growth studies, dry matter studies, days required for different growth stages, yield attributes and yield along with the nutrient uptake was recorded. The studies revealed that among the three genotypes, variety Niharika responded well to fertilizer level resulting in significant increase in growth, yield contributing characters and yield of the crop. Further it was found that application of fertilizer dose of 100:25 $\mathrm{NP} \mathrm{kg} / \mathrm{ha}$ recorded numerically higher values for growth, yield and quality characters and it was statistically found at par with $50: 25 \mathrm{NP} \mathrm{kg} / \mathrm{ha}$ fertilizer dose. Therefore, the application of $50: 25 \mathrm{NP} \mathrm{kg} / \mathrm{ha}$ dose to Niharika genotype would result to achieve higher isabgol yield rather than 100:25 NP kg/ha dose.

\section{Introduction}

Isabgol (Plantago ovata Forsk $2 n=2 x=8$ ) commercially known as bland Psyllium is one of the most important medicinal plant with commercial value. It belong to 'Plantaginaceae' family, This family consist of three genera viz. Bourgueria (Decne),
Littarella (Bergivs) and Plantago (L) and about 200 species which are either annual or perennial herb. The name isabgol is derived from two Persian word 'isap' and 'ghol' meaning horse ear, referring to characteristic shape of it's seed. It is herbaceous plant generally known as autumn sown annual. Plant height ranging from 40-45 cm and 
highly cross - pollinated crop and important part is husk and seed. Among species belonging to genus Plantago only two species $P$. ovata $F$. (bland psyllium or isabgol) and $P$. psyllium linn. (French psyllium) are economically important. Important part of isabgol is mucilage which is polysaccharide coating on seed. The separated husk is popularly known as 'Sat isabgol' in Indian market. It is used as medicine for intestinal and stomach disorder. It absorb moisture and form tasteless mucilaginous jelly. Jelly induces intestinal peristalsis for easy ejection and therefore useful in constipation. Refined husk is used in food industry, for manufacturing sausages, ice-creams and sauces.

\section{Materials and Methods}

The field experiment was conducted to study "Morpho physiological analysis of growth and yield of isabgol influenced by fertilizer levels". The details of material used and the method employed in conducting the research experiment are ,The experiment was conducted during the rabi season 2006-07 at Scheme for Medicinal and Aromatic Plants, Department of Botany, MPKV, Rahuri413722, District Ahmednagar (M.S.) (1947 N, 7401' E, 657.19 above M.S.L.). The average maximum and minimum temperature were $35.8^{\circ} \mathrm{C}$ and $9.2^{\circ} \mathrm{C}$ respectively. The average relative humidity at $7.30 \mathrm{hrs}$. (RH I) $71.48 \%$ and $14.30 \mathrm{hrs}$. (RH II) were $30.92 \%$. The experiment was conducted in the Randomized Block Design with six treatments replicated four times. The gross plot size was $3.60 \times 3 \mathrm{~m}^{2}$. The allocation of six treatments in four replications along with their symbols used are $\mathrm{T}_{1}$-GI-1 (50 N, $25 \mathrm{P} \mathrm{kg}$ ha $^{-1}$ dose), $\mathrm{T}_{2}$-GI-1 (100N, $50 \mathrm{P} \mathrm{kg} \mathrm{ha}^{-1}$ dose), $\mathrm{T}_{3}$-HI-5 (50 N, $25 \mathrm{P} \mathrm{kg} \mathrm{ha}^{-1}$ dose), T 4 -HI-5 (100 N, $50 \mathrm{P} \mathrm{kg} \mathrm{ha}^{-1}$ dose), T 5 Niharika $(50 \mathrm{~N}$, $25 \mathrm{P} \mathrm{kg} \mathrm{ha}^{-1}$ dose), T6-Niharika (100 N, $50 \mathrm{P}$ $\mathrm{kg} \mathrm{ha}^{-1}$ dose)

\section{Results and Discussion}

A field trial to study the "Morphophysiological analysis of growth and yield of Isabgol (Plantago ovate Forsk.) as influenced by fertilizer levels" was conducted during Rabi 2006-07. Fertilizers have pronounced effect on yield contributing characters and yield of isabgol and development of crop throughout the growing season. The yield is dependent on soil fertility, fertilizers applied and varieties used. The higher yield is the combination of several morphological, physiological and environmental factors. A comparison between different treatments in respect of yield revealed that yield increases numerically with fertilizer levels. However, both are at par with each other.

The yield contributing characters viz., seed weight, 1000 seed weight, highest husk yield plant $^{-1}$ found to be highest in genotype $V_{3}$ Niharika while lowest in $\mathrm{V}_{1}$ GI-1 genotype. The seed yield per plot and per hectare, highest biomass production were recorded significantly highest by genotype $\mathrm{V}_{3}$ (Niharika) while The genotype $\mathrm{V}_{2}$ (HI-5) recorded significantly the highest harvest index while the genotype $\mathrm{V}_{1}$ (GI-1) recorded significantly lowest harvest index. Thus, in general, by increasing the fertilizer level, their was liner increase in yield, Similar result reported by Randhawa et al., (1978). They found that highest seed yield Of Isabgol with nitrogen application @20 or 40 kg ha ${ }^{-1}$. Solanki and Shaktawat (1999) also found that $45 \mathrm{~kg} \mathrm{~N} \mathrm{ha}{ }^{-1}$ Significantly increased seed yield over control. Further Bist et al., (2001), Rathore and Chandawat (2003) and Utgikar et al., (2003) reported same results. The variety $\mathrm{V}_{3}$ (Niharika) produced more yield than varieties $\mathrm{V}_{2}$ ( HI-5) and $\mathrm{V}_{1}$ (GI-1). Response of all these Varieties to the fertilizer treatment was almost similar due to Which the interaction effects were not significant 
Sharma et al., (2003) noted that seed yield to the application of $45 \mathrm{~kg} \mathrm{~N} \mathrm{ha}^{-1}$. and straw yield were significantly higher up

Table.1 Effect of different fertilizer levels on seed weight per spike, 1000 seed weight (g) and husk yield per plant

\begin{tabular}{|c|c|c|c|}
\hline Treatment & $\begin{array}{l}\text { Seed weight } \\
\text { per spike(g) }\end{array}$ & $\begin{array}{l}1000 \text { seed } \\
\text { weight }(\mathrm{g})\end{array}$ & $\begin{array}{l}\text { Husk yield per } \\
\text { plant(g) }\end{array}$ \\
\hline \multicolumn{4}{|l|}{ Varieties } \\
\hline$V_{1}: G I-1$ & 0.17 & 1.77 & 0.70 \\
\hline $\mathrm{V}_{2}:$ HI-5 & 0.17 & 1.82 & 0.71 \\
\hline$V_{3}$ : Niharika & 0.18 & 1.82 & 0.76 \\
\hline S.E \pm & 0.002 & 0.008 & 0.003 \\
\hline CD at $5 \%$ & 0.005 & 0.025 & 0.009 \\
\hline \multicolumn{4}{|l|}{ Fertilizer dose $\left(\mathrm{Kg} \mathrm{ha}^{-1}\right)$} \\
\hline $\mathrm{L}_{1}: \mathbf{5 0 : 2 5 \mathrm { NP }}$ & 0.173 & 1.77 & 0.72 \\
\hline$L_{2}: 100: 50 \mathrm{NP}$ & 0.177 & 1.83 & 0.73 \\
\hline S.E \pm & 0.001 & 0.013 & 0.053 \\
\hline CD at $5 \%$ & N.S & N.S & N.S \\
\hline \multicolumn{4}{|l|}{ Interaction (AxB) } \\
\hline S.E \pm & 0.002 & 0.012 & 0.008 \\
\hline $\mathrm{CD}$ at $5 \%$ & N.S. & N.S. & N.S. \\
\hline
\end{tabular}

Table.2 Effect of different fertilizer levels on seed yield $\operatorname{plot}^{-1}$, seed yield ha ${ }^{-1}$, total biomass kg $\mathrm{ha}^{-1}$, harvest index and swelling factor

\begin{tabular}{|c|c|c|c|c|c|}
\hline Treatment & $\begin{array}{c}\text { Seed yield } \\
\text { per } \\
\operatorname{plot}(\mathrm{g})\end{array}$ & $\begin{array}{l}\text { Seed yield } \\
\left(\mathrm{kg} \mathrm{ha}^{-1}\right)\end{array}$ & $\begin{array}{c}\text { Total } \\
\text { Biomass } \\
\left(\mathrm{kg} \mathrm{ha}^{-1}\right)\end{array}$ & $\begin{array}{c}\text { Harvest } \\
\text { index } \\
(\%)\end{array}$ & $\begin{array}{l}\text { Swelling } \\
\text { Factor }\end{array}$ \\
\hline \multicolumn{6}{|l|}{ Varieties } \\
\hline $\mathrm{V}_{1}: \mathrm{GI}-1$ & 467.52 & 541.11 & 1484.5 & 36.45 & 10.92 \\
\hline $\mathrm{V}_{2}: \mathrm{HI}-5$ & 464.29 & 537.37 & 1314.46 & 40.88 & 10.96 \\
\hline$V_{3}:$ Niharika & 610.13 & 706.16 & 1806.6 & 39.08 & 10.87 \\
\hline S.E \pm & 6.214 & 6.949 & 8.634 & 0.700 & 0.082 \\
\hline CD at $5 \%$ & 18.724 & 20.614 & 26.018 & 2.120 & N.S. \\
\hline \multicolumn{6}{|c|}{ Fertilizer dose $\left(K_{\text {g. }}\right.$ ha $\left.^{-1}\right)$} \\
\hline $\mathrm{L}_{1}: 50: 25 \mathrm{NP}$ & 547.51 & 633.07 & 1523.36 & 41.55 & 11.63 \\
\hline$L_{2}: 100: 50 \mathrm{NP}$ & 564.38 & 653.22 & 1557.36 & 41.94 & 10.20 \\
\hline S.E \pm & 11.074 & 7.674 & 7.050 & 1.198 & 0.31 \\
\hline \multicolumn{6}{|l|}{ Interaction $(A \times x)$} \\
\hline S.E \pm & 8.788 & 14.828 & 12.211 & 2.075 & 0.116 \\
\hline CD at $5 \%$ & N.S. & N.S. & N.S. & N.S. & N.S. \\
\hline
\end{tabular}




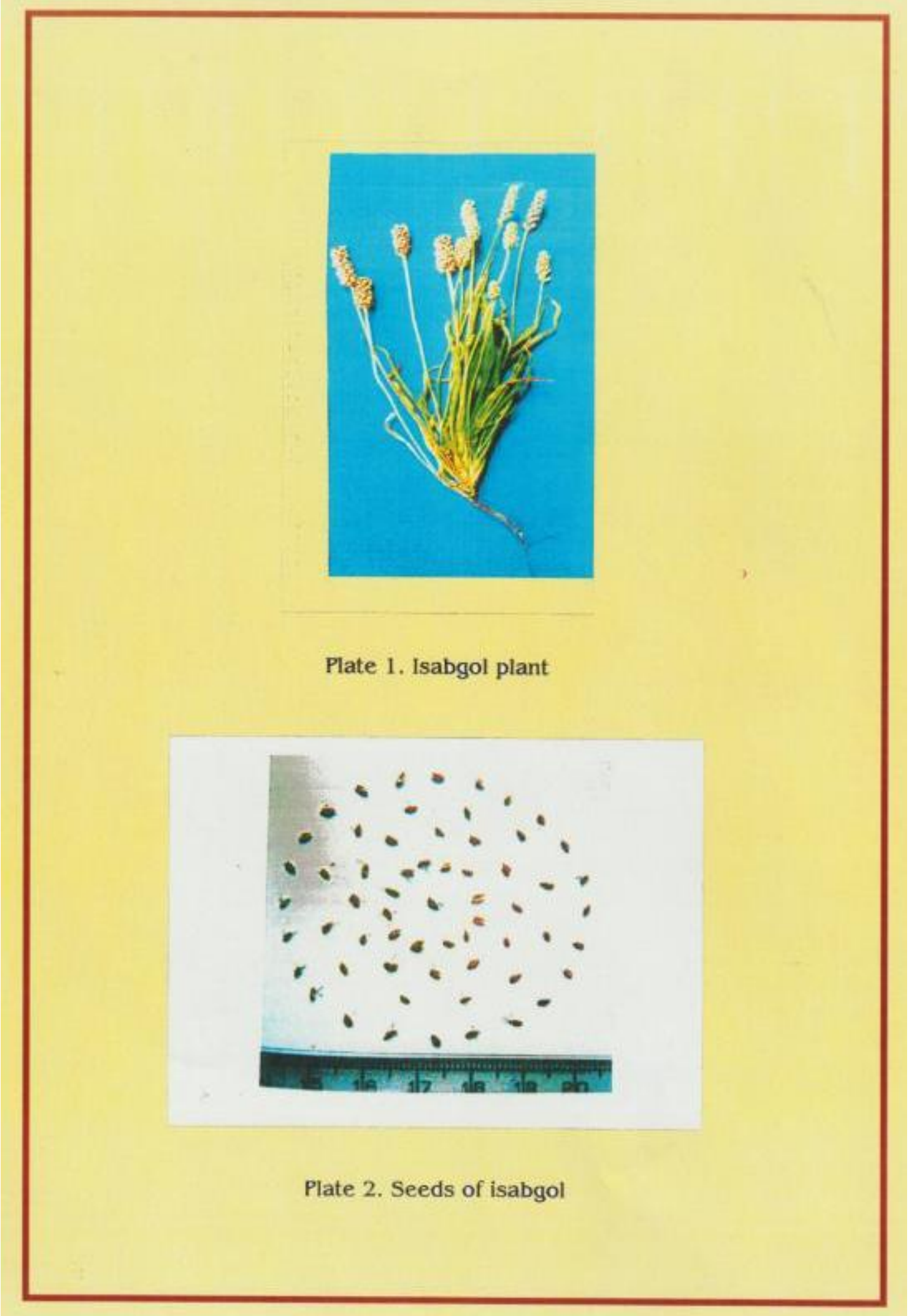




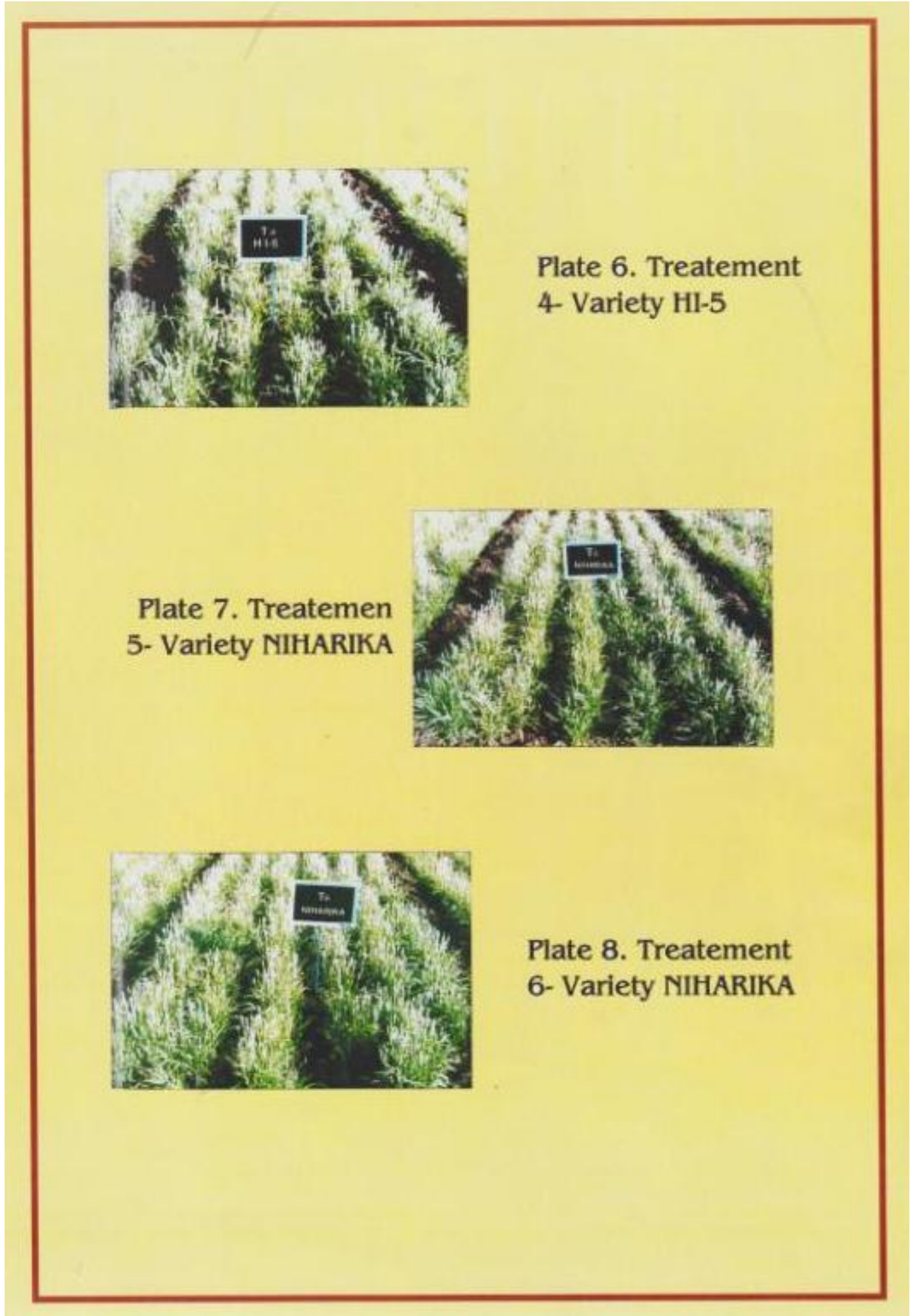




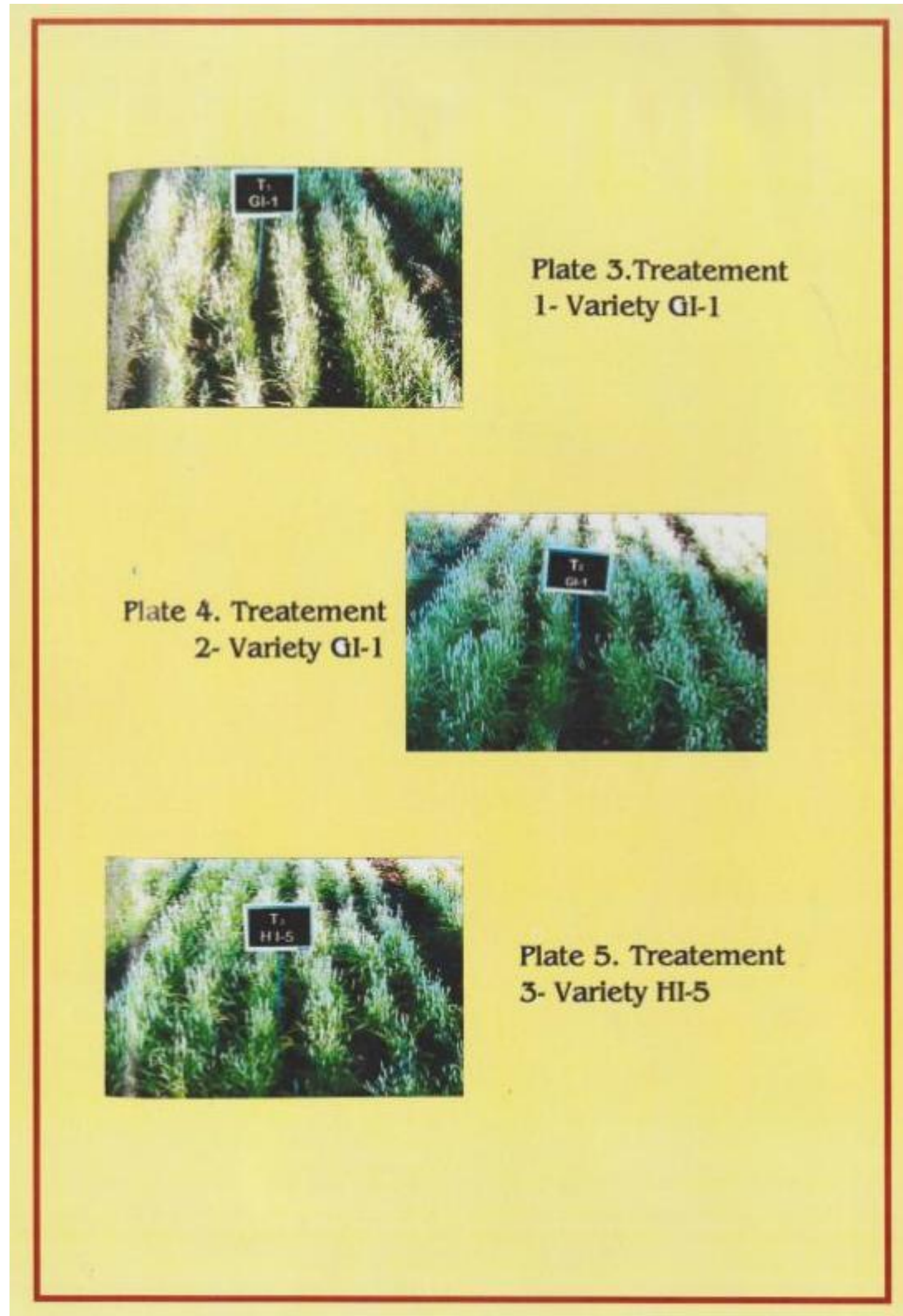

Singh and Chouhan (1994) concluded that $\mathrm{kg} \mathrm{N}+30 \mathrm{~kg} \mathrm{P}_{2} \mathrm{O}_{5}$ ha $^{-1}$ significantly increased with increasing levels of $\mathrm{N}$ and $\mathrm{P}_{2} \mathrm{O}_{5}$ upto 60 spikes plant- ${ }^{-}, 1000$ seed weight and seed 
yield. Rathore and Chandawat (2003) reported that Significant increase in seed and husk yield were recorded with increase in $\mathrm{N}$ from 0 to $30 \mathrm{~kg} \mathrm{ha}^{-1}$. Sharma et al., (2003) revealed that application of $45 \mathrm{~kg} \mathrm{~N} \mathrm{ha}{ }^{-1}$ increased significantly Seed weight plant $^{-1}$ Niharika recorded highest grain yield and 1000 grain weight. Among the three genotypes, variety $V_{3}$ (Niharika) responded well to fertilizer level resulting in significant increase in growth and yield contributing characters. Fertilizer dose 100:25 NP kg ha increased yield contributing characters and yield but, at par with 50:25 NP kg ha-1 fertilizer dose.

Recorded data numerically higher but statistically non-significant. Therefore, application of 50:25 NP kg ha ${ }^{-1}$ dose may be useful for increase the yield contributing characters and yield of isabgol. The combination of $\mathrm{V}_{3}$ (Niharika) variety and 50:25 NP kg ha ${ }^{-1}$ dose significantly increased all the growth and yield characters. It would be, therefore, advisable apply 50:25 NP kg ha ${ }^{1}$ dose to Niharika genotype.

\section{References}

Solanki, N.S. and Shaktawat, R.P.S. 1999. Effect of date of sowing and nitrogen on growth and yield of Isabgol(Plantago ovata). Ann. agri. Res. 20 (4) : 517-518.

Singh Ishwar and Chouhan, G.S. 1994. Effect of rnixtalol and different combinations of nitrogen and phosphorus fertilizer on growth and yield of psyllium (Plantagoovata). Indian J. Agron. 39 : 711-712.

Rathore, B.S. and Chandawat, M.S. 2003. Influence ofirrigation, row orientation and nitrogen on downy mildew of blond psyllium. Indian Phytopath. 56 (4) : 453-456.

Sharma, P.K., Yadav, G.L., Sudesh Kumar and Singh, M.N. 2003. Effect of methods of sowing and nitrogenlevel on the yield of psyllium (Plantago ovata). J. Medicinal and Aromatic Pl. Sci. 25 : 672-674.

Utgikar, S., Sadawarte, K.T., Wankhade, S.G. 2003. Growth and yield of Isabgol as influenced by nitrogen and phosphorus levels. Agric. Sci. Digest. 23 (1) : 7778.

\section{How to cite this article:}

Kuchekar, C. B., Madane Ananda Jaganath, P. P. Patil, M. K. Hiwrale and Ghodke, P. D. 2020. Study on Morpho-Physiological Traits in Isabgol (Plantago ovate Forsk.) Influenced by Different Fertilizer Levels. Int.J.Curr.Microbiol.App.Sci. 9(01): 2456-2462. doi: https://doi.org/10.20546/ijcmas.2020.901.280 